\title{
Pilot land of Biosoy new superior variety soybean for farmers in Wonoharjo Village, Boyolali Regency
}

\section{Lahan percontohan kedelai varietas unggul baru Biosoy bagi petani Desa Wonoharjo, Kabupaten Boyolali}

\author{
Sumarmi Sumarmi, Awaludin Sinur Kholis, Efi Nikmatu Sholihah \\ Departemen Agroteknologi, Fakultas Pertanian, Universitas Slamet Riyadi \\ Jl. Sumpah Pemuda No. 18 Surakarta, 57136, Indonesia
}

\begin{abstract}
ARTICLE INFO:
Received: 2021-07-22 Revised: 2021-09-05

Accepted: 2021-12-26

Keywords:

Biosoy soybean, Demonstration plot, Farmers

\section{ABSTRACT}

The area of soybean planting in Indonesia has decreased. The reduction in the land area causes a decrease in crop yields. Until now, 65\% of the soybeans needed by the Indonesian people come from other countries, so the creation of new land needs to be tried and the number of farmers who are able to grow soybeans must be increased. Farmers in Wonoharjo village, Kemusu, Boyolali Regency are trained to grow soybeans. Land preparation is done by adding liquid fertilizer which contains a lot of nitrogenfixing bacteria. 800 soybean seeds of Biosoy were planted with a spacing of $40 \mathrm{~cm}$ long and $20 \mathrm{~cm}$ wide. Biosoy's new high-yielding soybean seeds were selected to ensure a good harvest. Plant care by providing additional NPK fertilizer when soybeans are 40 days old, and cleaning weeds. Demonstration plot, lg 11 meters, a width of 4 meters with 400 growing points, produces 6.7 kilograms of dry soybeans from 200 grams of seed. The average number of pods per plant is 41 pieces. The average weight of 100 soybean seeds is 21.85 grams. The land that has never been planted with soybeans has succeeded as a Biosoy demonstration plot for farmers.
\end{abstract}

(C) 2022 Abdimas: Jurnal Pengabdian Masyarakat Universitas Merdeka Malang This is an open access article distributed under the CC BY-SA 4.0 license (https://creativecommons.org/licenses/by-sa/4.0/)

\begin{abstract}
How to cite: Sumarmi, S., Kholis, A. S., \& Sholihah, E. N. (2022). Pilot land of Biosoy new superior variety soybean for farmers in Wonoharjo Village, Boyolali Regency. Abdimas: Jurnal Pengabdian Masyarakat Universitas Merdeka Malang, 7(1), 139-148. https://doi.org/10.26905/abdimas.v7i1.6099
\end{abstract}

\section{PENDAHULUAN}

Swasembada kedelai sampai tahun 2020 belum dapat dicapai karena masih banyak hambatan yang dihadapi pemerintah. Hasil kedelai dalam negeri sampai saat ini belum memenuhi kebutuhan kedelai nasional (Sari et al., 2020). Produksi kedelai di Indonesia setiap tahunnya mengalami penurunan. Berdasarkan data Badan Pusat Statistik (2017), hasil dari tanaman kedelai di tahun 2015 sampai tahun 2017 mengalami penurunan, yaitu tahun 2015 sebesar 963.183 ton, menurun menjadi 859.653 ton pada tahun 2016, dan menurun kembali pada tahun 2017 menjadi 538.728 ton. Faktor yang mempengaruhi turunnya produksi kedelai di Indonesia yaitu minimnya lahan untuk bercocok tanam kedelai dan rendahnya penggunaan benih unggul. 
ABDIMAS: Jurnal Pengabdian Masyarakat Universitas Merdeka Malang

Volume 7, No 1, February 2022: 139-148

Minat petani dalam menanam kedelai mulai tahun 2008 sampai 2015 terus mengalami penurunan. Luas panen kedelai tahun 2018 sampai 2020 diperkirakan mengalami penurunan 0,72 hektar. Hasil panen 0,96 juta ton menurun menjadi 0,94 juta ton (Pitasari, et al. 2018). Pada tahun 2020 produksi kedelai nasional mencapai 1.475.965 ton sedangkan konsumsi kedelai nasional mencapai 3.012.377 ton, sehingga terjadi defisit rata-rata sebesar 1,6 juta ton per tahun (Aldillah, 2015).

Hambatan malas bertanam kedelai karena dianggap mengeluarkan biaya perawatan tinggi dan tidak sebanding dengan harga jual setelah panen kedelai. Hambatan dapat juga disebabkan oleh faktor sumber daya manusia, contoh faktor situasi dan kondisi petani. Salah satu hambatan yaitu banyak petani tidak tahu dan tidak mau menanam kedelai. Tidak tahu karena belum melihat langsung atau belum ada yang menunjukkan cara budidaya kedelai. Tidak mau karena berpikir negatif bahwa bertanam kedelai itu sulit, sering rugi, banyak hama dan penyakit, maupun alasan lain. Padahal kedelai sudah puluhan tahun terus menerus diimpor dari luar negeri, artinya kemandirian pangan di bidang kedelai masih menjadi masalah dan belum dapat mencukupi kebutuhan dalam negeri. Masalah ini perlu sedikit demi sedikit dicarikan solusi untuk mengatasi permasalahan seputar budidaya kedelai.

Biosoy merupakan varietas unggul baru, hasil dari Balai Penelitian Bioteknologi dan Pengembangan Sumberdaya Genetik, Departemem Pertanian di Bogor. Biosoy diluncurkan tahun 2017, telah diujicoba di Provinsi Lampung, Sulawesi Utara, Jawa Barat, dan Jawa Timur. Biosoy ditemukan untuk menjawab persoalan rendahnya produksi kedelai serta ukuran biji. Hasil panen Biosoy dapat mencapai 3 ton per hektar, terbesar sepanjang sejarah penemuan varietas unggul baru kedelai. Berat 100 biji kedelai mencapai 23 gram, jauh lebih besar dari varietas kedelai lainnya yaitu Anjasmoro dan Grobogan sekitar 16 gram tiap 100 biji.

Pada tahun 2019 dan 2020 telah dilakukan penanaman kedelai Biosoy di Jawa Barat dan beberapa daerah lain, terutama untuk penelitian dan memenuhi kebutuhan benih. Laporan penelitian menunjukkan bahwa tinggi tanaman kedelai Biosoy $48 \mathrm{~cm}$, hampir sama dengan varietas Grobogan, akan tetapi lebih rendah dari kedelai Anjasmoro yang dapat mencapi $67 \mathrm{~cm}$ (Asadi et al., 2020). Kestabilan habitus tanaman kedelai Biosoy perlu diteliti dengan cara ditanam di berbagai lahan untuk melihat pengaruh lokasi terhadap pertumbuhan dan hasilnya.

Pertumbuhan benih kedelai Biosoy dapat dipengaruhi oleh perubahan lingkungan. Kondisi lingkungan yang sesuai diharapkan akan mempertahankan mutu benih. Kondisi lingkungan yang tidak sesuai dapat berpengaruh menurunkan hasil panen. Hasil penelitian menunjukkan bahwa hasil panen kedelai varietas baru Biosoy mencapai 2,3 sampai 2,7 ton per hektar. Hasil tersebut lebih tinggi dibandingkan dengan varietas Grobogan dan Anjasmoro yang mencapai 2,1 sampai 2,2 ton per hektar. Selanjutnya perlu dilakukan penelitian untuk membuktikan bahwa hasil panen kedelai Biosoy mencapai 3 ton per hektar.

Varietas unggul baru kedelai Biosoy masih perlu dikenalkan kepada masyarakat luas. Hal itu dilakukan karena varietas ini dapat menghasilkan hingga 3 ton per hektar. Keunggulan lain dari kedelai berbiji besar ini (22 gram tiap 100 biji) adalah tahan terhadap serangan penyakit, terutama karat daun.

Sebagian besar petani Desa Wonoharjo, Kemusu, Boyolali, belum pernah bertanam kedelai. Lahan di desa tersebut lebih sering ditanami jagung, setelah satu kali ditanami padi karena merupakan lahan tadah hujan. Salah satu lahan milik orang tua dari mahasiswa Fakultas Pertanian Universitas Slamet Riyadi akan digunakan untuk membuat lahan percontohan kedelai. Alasan atau latar belakang diusulkannya rencana membuat lahan percontohan karena untuk mengedukasi warga desa setempat, bahwa lahan di Desa Wonoharjo dapat ditanami kedelai asal menggunakan benih unggul. Lahan percontohan tersebut akan diberi perlakuan khusus dengan menggunakan sangat banyak pupuk yang mengandung Nitrogen, karena kandungan utama biji kedelai adalah protein yang proses pembentukannya memerlukan banyak Nitrogen. 


\section{Pilot land of Biosoy new superior variety soybean for farmers in Wonoharjo Village, Boyolali Regency}

Sumarmi Sumarmi, Awaludin Sinur Kholis, Efi Nikmatu Sholihah

Banyak petani berpikir bahwa bertanam kedelai itu rumit dan memerlukan biaya dan tenaga lebih banyak dibandingkan dengan bertanam jagung. Anggapan petani yang demikian tidak semuanya keliru, tetapi yang penting adalah edukasi untuk menunjukkan kelebihan, keuntungan, dan manfaat bertanam kedelai. Perlu usaha untuk mengajak para petani agar mau menanam kedelai. Pembukaan lahan baru dapat dilakukan apabila petani bersedia bertanam kedelai. Kesanggupan petani untuk menanam kedelai sebaiknya bukan karena terpaksa tetapi tertarik untuk ikut mencoba menanam kedelai. Membuat lahan percontohan di lahan yang belum pernah ditanami kedelai merupakan salah satu usaha agar petani berminat untuk menanam kedelai.

Bagi petani yang sudah terbiasa menanam jagung dan belum pernah bertanam kedelai dapat timbul beberapa pertanyaan. Apakah di Desa Wonoharjo, Kemusu, Boyolali dapat ditanami kedelai? Pertanyaan dan keraguan itu muncul karena di desa tersebut belum pernah ditanami kedelai. Petani lebih terbiasa bertanam jagung atau palawija lain yang tahan kekeringan. Keraguan mungkin akan berlangsung lama apabila tidak ada keberanian untuk mencoba menanam kedelai.

Benih varietas unggul baru yaitu Biosoy akan diuji coba ditanam karena sifat-sifat varietas tersebut yang bisa beradaptasi dengan kondisi bermacam-macam jenis tanah. Saat yang tepat untuk menanam kedelai adalah setelah akhir musim hujan. Pada saat itu masih ada air, kadar air tanah masih cukup untuk menumbuhkan benih kedelai. Sesuatu yang baru perlu dicoba dan dimulai untuk tujuan yang baik. Lahan percontohan akan dibuat di Desa Wonoharjo, Kecamatan Kemusu, Kabupaten Boyolali, mengggunakan benih kedelai varietas unggul baru yaitu Biosoy. Lahan dan tanaman akan dirawat dengan sungguhsungguh supaya berhasil menjadi percontohan budidaya kedelai. Sesuai dengan latar belakang bidang ilmu ketua pengusul, pelaksanaan pengabdian masyarakat akan dibuat agar bermanfaat bagi masyarakat setempat maupun tujuan yang lebih luas.

Petani Desa Wonoharjo perlu ditunjukkan bahwa lahan sawah desa mereka dapat untuk bertanam kedelai. Cara pembelajaran yang mudah yaitu dengan membuat lahan percontohan kedelai, dengan memilih benih varietas unggul baru yaitu Biosoy. Lahan percontohan akan disiapkan dan dirawat dengan baik sampai berhasil panen. Pemilihan benih kedelai varietas Biosoy untuk menjamin keberhasilan program. Tujuan jangka panjang pengabdian masyarakat dilakukan untuk meningkatkan hasil panen kedelai, karena produksi kedelai skala nasional masih jauh dari target dan harapan. Hal itu disebabkan oleh banyak faktor seperti lahan yang terus berkurang, tenaga perawatan tanaman kedelai lebih banyak yang harus dicurahkan, banyaknya hama, penyakit dan gulma di sekitar lahan penanaman kedelai, dan sebagainya. Pengabdian masyarakat ini bertujuan untuk mengatasi sebagian kecil dari banyaknya masalah yang berhubungan dengan pertanian kedelai.

Kegiatan dari program pengabdian ini adalah membuat lahan percontohan kedelai varietas unggul baru (VUB) Biosoy. Hasil lain yang diharapkan berupa perbaikan kondisi sosial masyarakat yaitu mengedukasi petani, apabila menggunakan benih unggul kedelai dan melakukan pengendalian terhadap gulma di lahan penanaman maka hasil panen kedelai akan meningkat. Proses pembelajaran ini penting bagi petani maupun mahasiswa Fakultas Pertanian UNISRI yang terlibat sebagai tim pengabdi karena kegiatan ini berdasarkan teori, nalar, logika, dan ilmu yang telah dipelajari selama kuliah. Benih unggul akan menjamin keberhasilan pertumbuhan tanaman sampai berhasil berbuah dan panen dengan baik. Benih kedelai dan pengendalian gulma bukan satu-satunya penentu keberhasilan peningkatan produksi kedelai karena faktor lingkungan dan agroklimat juga penting. Tim pengabdian akan mengusahakan untuk keberhasilan pelaksanaan. Program pengabdian ini bertujuan untuk membuat lahan percontohan tanaman kedelai bagi petani Desa Wonoharjo, Kemusu, Boyolali mulai dari proses penanaman sampai selesai panen. 
ABDIMAS: Jurnal Pengabdian Masyarakat Universitas Merdeka Malang

Volume 7, No 1, February 2022: 139-148

\section{METODE}

Pelaksanaan pengabdian kepada masyarakat dilakukan secara bertahap dan berjalan terus sejak persiapan lahan sampai panen. Proses pembuatan lahan percontohan tanaman kedelai varietas unggul baru Biosoy adalah sebagai berikut: (1) Survey ke lokasi. Dimulai pada tanggal 27 Februari 2021, untuk membuat dan menentukan rencana keseluruhan pembuatan lahan percontohan yang akan ditanami kedelai Biosoy. Hal itu penting dilakukan mengingat lahan tersebut belum pernah ditanami kedelai. Menurut teori, lahan yang demikian dapat ditanami kedelai akan tetapi tidak akan bisa membentuk buah polong. Hal-hal seperti ini perlu diantisipasi supaya pengabdian masyarakat ini berhasil dan bermanfaat; (2) Persiapan pembuatan lahan. Perencanaan yang baik, lengkap, dan terperinci dapat menentukan keberhasilan program pembuatan lahan percontohan. Persiapan itu berupa memperkirakan kebutuhan benih kedelai, jumlah, dan macam pupuk yang akan digunakan, menentukan saat yang tepat untuk mulai menanam; (3) Pengolahan lahan. Saat proposal ini dibuat, lahan masih ditanami jagung. Pengolahan lahan mulai dilakukan setelah semua tanaman jagung dipanen pada tanggal 4 Maret 2021. Tanah dibalik menggunakan traktor, semua gulma dihilangkan, diberi pupuk dan dicampur secara merata di seluruh lahan lalu dibuat larikan dan bedengan.

Langkah selanjutnya: (4) Penanaman kedelai varietas unggul baru Biosoy. Biji kedelai ditanam dengan jarak $40 \times 20 \mathrm{~cm}$, setiap lubang tanam diisi 2 biji, kedalaman tanah untuk menanam $3 \mathrm{~cm}$, lalu ditutup tanah, dibiarkan sampai tumbuh tanaman baru. Dilakukan pada tanggal 11 Maret 2021; (5) Perawatan tanaman. Diharapkan umur 2 minggu setelah biji ditanam, semua biji sudah tumbuh sekitar $10 \mathrm{~cm}$ dan muncul 4 daun. Perawatan tanaman dilakukan apabila ada hama yang menyerang tanaman muda. Minimal seminggu sekali tanaman dilihat untuk memastikan tumbuh normal. Gulma yang tumbuh dihilangkan pada umur 30-40 hari supaya cepat berbunga dan dilakukan pemupukan ke dua supaya tanaman tumbuh dengan baik, subur dan daun hijau segar tidak pucat; (6) Pemantauan. Dilakukan untuk meninjau kondisi pertumbuhan tanaman. Semakin sering ditinjau dapat diketahui kalau ada hambatan pertumbuhan dan segera dilakukan tindakan yang tepat, misalnya apabila ada serangan hama dan penyakit tanaman atau tanaman tumbuh kerdil; (7) Panen. Dilakukan sesuai umur panen yaitu 82-85 hari, pada tanggal 5 Juni 2021 dengan cara mencabut seluruh tanaman, mengambil semua hasil buah polong, kemudian dipanaskan di bawah sinar matahari sampai kering. Buah polong kedelai akan dirontokkan untuk diambil bijinya, lalu dikumpulkan dalam satu wadah kering yang tertutup; (8) Evaluasi dan diskusi dengan petani. Diskusi dengan masyarakat desa dilakukan untuk mengedukasi petani, berbagi pengalaman, dan menarik warga lain agar mau menanam kedelai. Pengalaman keberhasilan penanaman kedelai perlu disebarluaskan kepada petani dan mahasiswa. Petani perlu belajar dan akhirnya akan terbiasa menanam kedelai.

\section{HASIL DAN PEMBAHASAN}

Pengabdian masyarakat telah dilaksanakan mulai tanggal 27 Februari hingga 5 Juni 2021, di lahan sawah desa Wonoharjo, kecamatan Kemusu, Kabupaten Boyolali. Lokasi yang dipergunakan untuk pertemuan dengan para petani di rumah orang tua mahasiswa Fakultas Pertanian Universitas Slamet Riyadi.

\section{Survey ke lokasi}

Peninjauan lokasi dilakukan pada akhir Februari 2021 untuk menentukan layak dan tidaknya lahan yang akan dibuat untuk percontohan. Lahan tersebut belum pernah ditanami kedelai sebelumnya. Ini 
merupakan tantangan tersendiri, karena ada kemungkinan kedelai gagal tumbuh atau gagal panen. Lokasi yang disurvei akhirnya disetujui sebagai lahan percontohan kedelai mengingat jika berhasil maka benar-benar dapat sebagai tempat belajar langsung bagi petani setempat. Lokasi lahan percontohan mudah dijangkau, berada di tepi jalan desa yang mudah dilalui semua moda angkutan seperti sepeda hingga mobil.

\section{Persiapan lahan}

Pada akhir Februari 2021 olah tanah dilakukan dengan mencangkul untuk membalik tanah. Lahan sebelumnya belum pernah ditanami kedelai diberi pupuk cair yang mengandung banyak bakteri penambat Nitrogen (Puspitasari \& Elfarisna, 2017). Luas lahan 44 meter persegi dengan panjang 11 meter, lebar 4 meter. Dibuat 4 guludan tanah memanjang dengan jarak 1 meter. Saluran drainase/irigasi dibuat dengan kedalaman $25-30 \mathrm{~cm}$ dan lebar $20 \mathrm{~cm}$. Saluran ini berfungsi untuk mengurangi kelebihan air bila lahan terlalu becek, dan sebagai saluran irigasi pada saat tanaman perlu tambahan air.
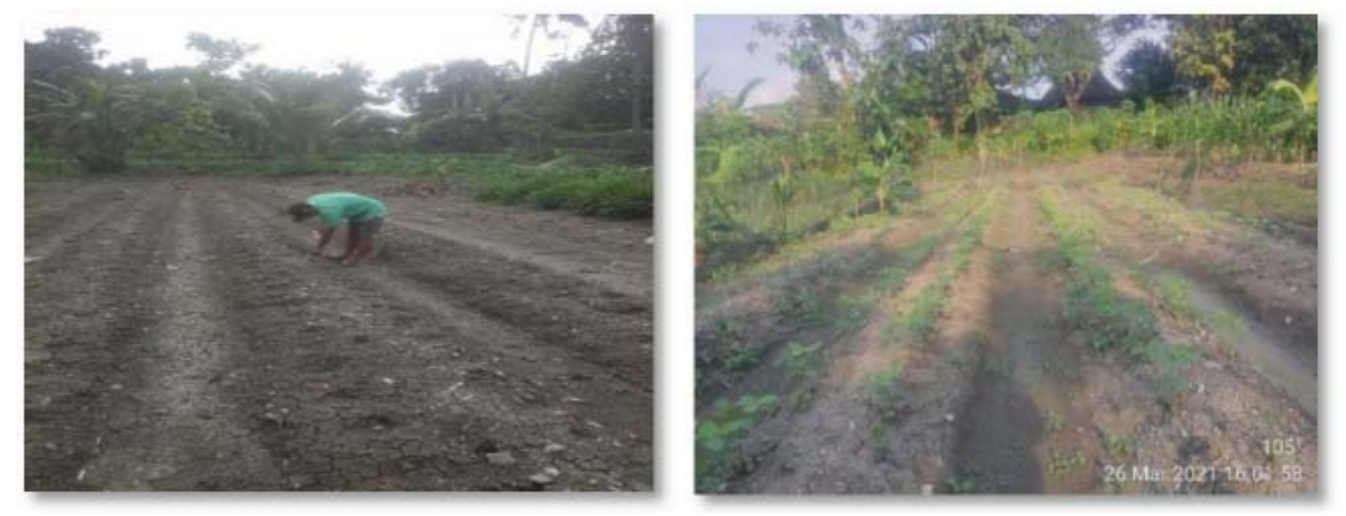

Gambar 1. Penanaman biji kedelai

Gambar 2. Tanaman kedelai mulai tumbuh

\section{Penanaman}

Bahan utama yang ditanam adalah benih kedelai Biosoy sebanyak 800 butir. Bahan penting untuk menjaga pertumbuhan yaitu pupuk cair, kompos, dan pupuk NPK. Benih didapat dari BB Biogen, Bogor, diterima pada Agustus 2020. Cara tanam dibuat jarak tanam $20 \times 40 \mathrm{~cm}$, tiap lubang ditanam 2 biji kedelai. Satu deret ada 100 titik tanam, telah dibuat 4 deret tanaman kedelai, atau sama dengan ada 400 lubang tanam (Gambar 1). Benih kedelai telah ditanam dengan tugal, kedalaman 2-3 cm. Pada umur 2 minggu 95\% benih yang ditanam telah tumbuh menjadi tanaman baru (Gambar 2). Tinggi tanaman mulai tampak $3 \mathrm{~cm}$ dan terus tumbuh memanjang, jumlah daun mula-mula 2 menjadi 6 lembar dengan tunas baru. Model penanaman kedelai tiap daerah berbeda. Penanaman kedelai di Desa Sukajadi, Kecamatan Talang Kelapa, Kabupaten Banyuasin, Sumatera Selatan dilakukan pada Juni sampai Agustus, hasil terbaik menggunakan varietas Dega 1 dengan jarak tanam $25 \times 40 \mathrm{~cm}$ (Astuti et al., 2021).

\section{Perawatan tanaman}

Pada umur 30 hari, tanaman diberi pupuk NPK dengan cara ditaburkan di sekitar tanaman. Setiap seminggu sekali gulma yang tumbuh dicabut, supaya tidak mengganggu pertumbuhan tanaman kedelai (Gambar 3). Penyiraman tidak dilakukan karena pada bulan April masih turun hujan. Hal tersebut menguntungkan karena tanaman kedelai tumbuh subur, tanpa kekurangan air (Gambar 4). Pada umur 40 hari tanaman mulai berbunga, satu tanaman dapat menghasilkan lebih dari 10 bunga. 
ABDIMAS: Jurnal Pengabdian Masyarakat Universitas Merdeka Malang Volume 7, No 1, February 2022: 139-148
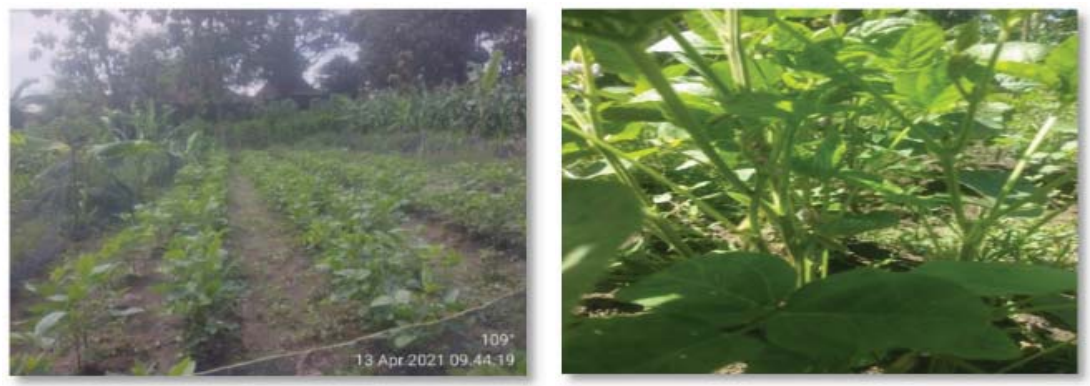

Gambar 3. Tanaman kedelai umur 30 hari

Gambar 4. Tanaman kedelai tumbuh subur

\section{Panen}

Dilakukan pada saat polong kedelai telah masak penuh, kulit polong berwarna cokelat, ditandai dengan sebagian daun menguning. Panen dilakukan pada tanaman umur 85 hari (Gambar 5). Cara panen dengan mencabut seluruh tanaman, kemudian dikumpulkan dan dikeringkan di bawah sinar matahari selama 7 hari (Gambar 6). Biasanya biji kedelai akan keluar dari buah polong yang terbuka sendiri karena kekeringan. Semua biji dikumpulkan pada satu tempat.
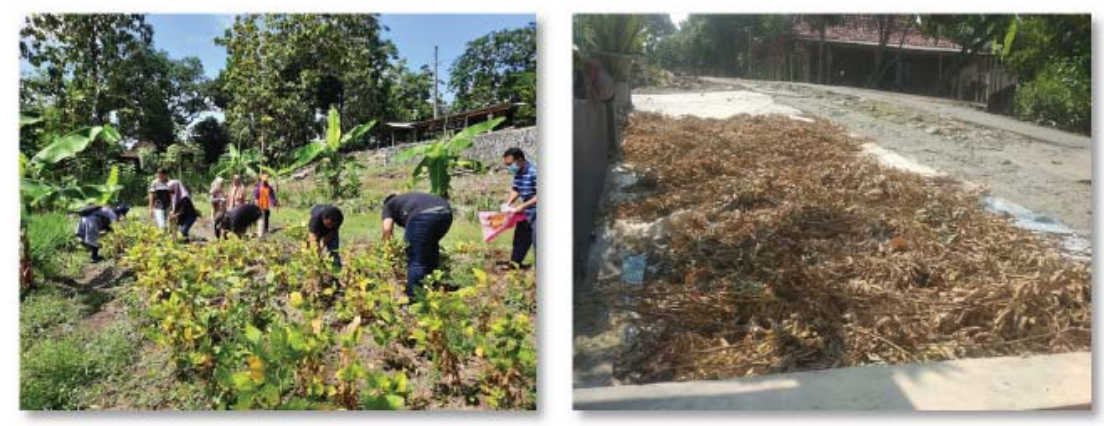

Gambar 5. Panen kedelai di lahan Gambar 6. Hasil panen kedelai dijemur

Tabel 1. Kondisi 10 sampel tanaman hasil panen kedelai Biosoy

\begin{tabular}{cccc}
\hline Tinggi tanaman $(\mathbf{c m})$ & Jumlah daun (helai) & Jumlah buah polong \\
\hline 33 & 45 & 37 \\
42 & 38 & 41 \\
40 & 39 & 47 \\
45 & 39 & 30 \\
33 & 42 & 44 \\
40 & 36 & 50 \\
& 40 & 45 & 40 \\
& 40 & 38 & 56 \\
Rata-rata & 30 & 48 & 30 \\
\hline
\end{tabular}


Pada saat panen, diambil 10 tanaman sampel untuk diamati dan dicatat hasilnya. Tanaman kedelai Biosoy yang tumbuh di lahan percontohan cukup bervariasi habitusnya, tinggi tanaman tidak seragam, jumlah daun dan jumlah buah polongnya juga berbeda antara satu tanaman dengan tanaman lain (Tabel 1). Hasil panen tersebut menggembirakan karena Biosoy dapat tumbuh dan berbuah, artinya lahan di Desa Wonoharjo dapat untuk budidaya tanaman kedelai.

\section{Pertemuan dengan petani}

Dilakukan dengan mengundang 10 petani di sekitar lokasi penanaman kedelai menjelang panen untuk menjelaskan cara bertanam kedelai, keuntungan dan kelebihan kedelai dibandingkan dengan jagung (Gambar 7). Petani diajak melakukan panen dan melihat hasil panen kedelai, diharapkan mulai tertarik untuk bertanam kedelai. Dalam pertemuan tersebut dijelaskan tentang budidaya kedelai serta pentingnya bertanam kedelai. Tanya jawab dan evaluasi pelaksanaan pembuatan lahan percontohan kedelai dilakukan untuk meyakinkan petani bahwa lahan Desa Wonorejo dapat digunakan untuk menanam kedelai.

Menurut pengalaman petani Desa Mojoreno, Sidoharjo, Wonogiri dalam kondisi yang baik setiap $1 \mathrm{~kg}$ benih kedelai akan menghasilkan $30 \mathrm{~kg}$ kedelai hasil panen, atau 30 kali lipat dari berat benih yang ditanam (Sumarmi \& Triyono, 2018). Pada akhir masa tanam dan setelah dipanen, hasil panen uji coba lahan di Wonoharjo, Kemusu, Boyolali, ditimbang dan dibandingkan antara jumlah berat kedelai yang ditanam dengan hasil panen kedelai Biosoy. Menurut teori akan tercapai karena Biosoy merupakan kedelai varietas unggul baru dengan prediksi hasil panen 3 ton per hektar.
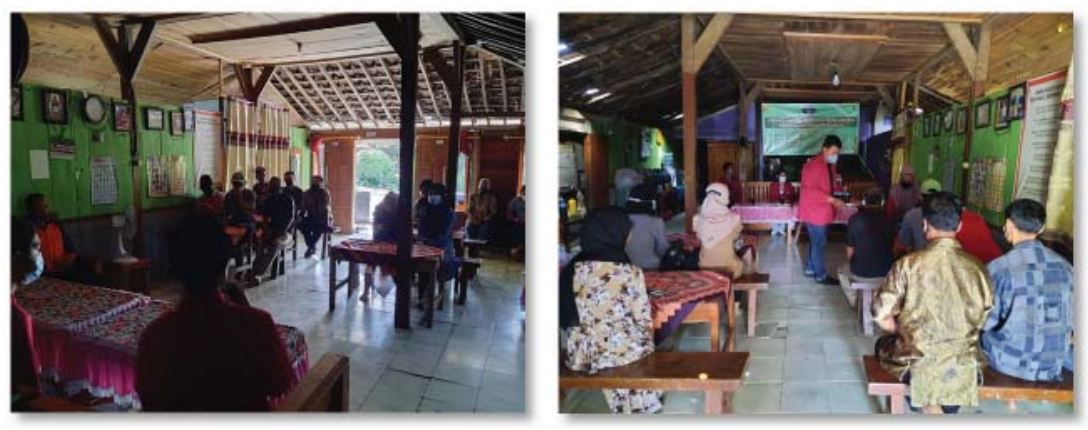

Gambar 7. Pertemuan dengan petani Desa Wonoharjo, Kemusu, Boyolali

Demonstrasi plot atau lahan percontohan yang dibuat ditanami dengan Biosoy, varietas unggul baru kedelai berukuran 11 kali 4 meter. Benih yang ditanam banyak 800 biji kedelai atau 200 gram beratnya. Berat 100 biji kedelai varietas unggul baru Biosoy 25 gram. Benih kedelai unggul yang pernah ada sebelumnya seperti Anjasmoro, Grobogan, atau Argomulyo termasuk berbiji besar tetapi berat 100 biji berkisar antara 18-20 gram. Benih Biosoy yang ditanam berbiji lebih besar dari varietas sebelumnya, warna kulit biji kuning, mirip dengan biji kedelai impor yang disukai petani.

Awal pertumbuhan yaitu Maret, 95\% kecambah kedelai tumbuh menjadi tanaman kecil dengan baik. Hal ini dapat dipengaruhi oleh penggunaan pupuk cair yang banyak mengandung Rhizobium (Ardyawan et al., 2018). Pupuk cair tersebut diserap akar dengan baik (Sari et al., 2020). Pada April sampai dengan Mei masih ada hujan di daerah Kemusu, Boyolali. Hal tersebut menguntungkan karena pertumbuhan kedelai berlangsung secara normal. Tahap tumbuhnya bunga pada umur 40-42 hari berlangsung sesuai perkiraan. Jumlah bunga yang tumbuh di ketiak daun juga normal, dan setelah 5 hari berkembang menjadi polong kecil, sekitar $0,8 \mathrm{~cm}$. Jumlah polong yang terbentuk tiap tanaman berkisar 
ABDIMAS: Jurnal Pengabdian Masyarakat Universitas Merdeka Malang

Volume 7, No 1, February 2022: 139-148

antara 30 sampai 56 buah, ini termasuk normal atau hampir semua bunga kedelai berkembang menjadi buah polong. Perkembangan tanaman setelah umur 50 hari berlangsung dengan baik, batang kokoh kuat, hampir semua polong bernas atau berisi calon biji kedelai.

Persamaan jagung dan kedelai adalah dapat hidup pada musim kemarau, pada kondisi sedikit air hujan. Beda kedelai dan jagung terutama pada manfaat atau fungsi ke dua bahan tersebut berbeda. Jagung adalah bahan pangan penghasil karbohidrat yang menimbulkan rasa kenyang. Kedelai adalah bahan pangan biji-bijian yang banyak mengandung protein nabati yang dapat dibuat menjadi aneka olahan (Septifani, 2018).

Proses penanaman dan pertumbuhan jagung serta kedelai sedikit berbeda karena kedelai membutuhkan banyak unsur Nitrogen untuk pengisian biji, sedangkan jagung hanya sedikit memerlukan unsur $\mathrm{N}$ selama proses pembentuikan biji (Wahyudin et al., 2017). Jagung dapat tumbuh tinggi lebih dari 1 meter, sedangkan kedelai tidak lebih dari $70 \mathrm{~cm}$. Secara sistematika, kedelai adalah tanaman dikotil yang berakar tunggang, sedangkan jagung adalah tanaman monokotil yang berakar serabut.

Pertumbuhan kedelai di lahan percontohan secara umum termasuk berhasil tumbuh dengan baik. Hal tersebut menggembirakan tim pengabdian karena pada awal penanaman ada rasa ragu dan khawatir jikalau sampai gagal tumbuh. Selama pertumbuhan hampir tidak ada serangan hama dan penyakit yang berarti. Kedelai tumbuh normal, tanaman sehat sampai menjelang panen.

Berdasarkan data pada Tabel 1 maka tanaman kedelai varietas baru Biosoy yang tumbuh di lahan percontohan Desa Wonoharjo, Kemusu, Kabupaten Boyolali dapat dikatakan berhasil tumbuh dengan baik. Tanaman kedelai tidak tumbuh tinggi, tetapi berdaun lebat dan setiap tanamannya dapat menghasilkan rata-rata 41 buah polong kedelai. Pengeringan hasil panen bersama polong kedelai dilakukan di bawah sinar matahari dengan cara menjemur tanaman, disusun berjajar, dan diberi alas lembaran plastik yang cukup lebar. Tujuan penggunaan alas plastik untuk menampung biji-biji kedelai yang pecah dan keluar dari polong kedelai yang telah benar-benar kering. Proses pengeringan dilakukan selama 7 hari untuk memudahkan pengambilan biji kedelai dari polongnya.

Total hasil biji kedelai kering yang dihasilkan sebanyak 6,7 kilogram, menunjukkan keberhasilan proses pembuatan lahan percontohan. Sedangkan hasil pengamatan pada tiap 100 biji kedelai beratnya mencapai 21,85 gram. Berat 100 biji kedelai Biosoy yang ditanam di lahan percontohan tersebut termasuk kedelai berbiji besar. Warna kulit biji kedelai putih kekuningan, mirip kedelai impor.

Petani Desa Wonoharjo, Kemusu, Boyolali selama ini hanya mengenal bertanam jagung karena menganggap bahwa tanah di desa tersebut hanya cocok untuk tanaman jagung. Faktor penunjang lainnya karena hasil panen jagung sudah ada yang menampung, pasarnya jelas, atau hasil panen bisa langsung dijual. Selain memikirkan keuntungan, petani perlu diberi edukasi untuk menggunakan bahan lokal untuk mengawetkan tanah dan lingkungan. Petani yang diedukasi secara terus menerus akan berubah pola kebiasaan menggunakan pestisida kimia, diganti dengan pestisida organik (Haryadi et al., 2021). Bertanam kedelai di desa tersebut merupakan hal baru, oleh karena itu perlu dikenalkan kepada para petani. Metode yang mudah dilakukan adalah contoh langsung agar petani melihat dari dekat sejak penanaman sampai panen. Langkah berikutnya yaitu lahan percontohan tersebut harus berhasil dan hasil panenya menarik. Faktor lain tentu saja menjelaskan dan menjawab pertanyaan yang diberikan petani kepada tim pengabdian.

Tujuan pembuatan lahan percontohan adalah untuk memberi contoh kepada petani dan masyarakat Desa Wonoharjo, Kemusu, Kabupaten Boyolali bahwa kedelai Biosoy dapat tumbuh dengan baik di desa ini. Petani dan masyarakat desa merupakan tujuan utama untuk dilatih dan dikenalkan dengan tanaman kedelai. Berdasarkan pemantauan, lahan percontohan tersebut menarik perhatian karena banyak yang 
bertanya itu tanaman apa, atau apakah itu tanaman kedelai. Lahan yang ditanami lebih baik daripada lahan yang dibiarkan terbuka tanpa tanaman. Lahan percontohan yang ditanami akan menguntungkan secara ekonomi dan dapat meningkatkan produktivitas lahan terrsebut (Mursalin et al., 2020). Lahan percontohan dengan tanaman kedelai tidak merubah fungsi lahan, akan tetapi mempertahankan lingkungan dan menambah manfaat bagi masyarakat desa (Mayarni \& Habibie, 2017).

Hasil panen adalah 6,7 kilogram kedelai kering. Dilihat dari benih yang hanya 200 gram atau 2 ons maka hasil kedelai sudah berlipat 33 kalinya. Hal itu menunjukkan bahwa lahan percontohan yang dibuat berhasil dengan baik. Harapannya ada petani yang tertarik untuk menanam kedelai varietas baru tersebut. Bulan Juni masih termasuk waktu bertanam kedelai yang cukup baik. Ternyata ada petani yang mau mencoba bertanam. Saat ini telah ditanam kedelai di desa tersebut seluas 200 meter persegi, menggunakan benih kira-kira 1 kilogram dari hasil panen sebelumnya yang telah dipilih.

\section{SIMPULAN DAN SARAN}

Tujuan pengabdian masyarakat untuk membuat lahan percontohan kedelai. Pengabdian masyarakat telah selesai dan mendapatkan hasil biji kedelai Biosoy kering sebanyak 6,7 kilogram dari 200 gram benih yang ditanam. Hal ini menunjukkan bahwa lahan di Desa Wonoharjo, Kemusu, Kabupaten Boyolali ternyata cocok dan sesuai sebagai percontohan tanaman kedelai serta dapat digunakan untuk memperluas areal penanaman kedelai varietas unggul baru Biosoy. Lahan baru yang belum pernah ditanami kedelai akan berhasil ditanami kedelai apabila tanaman dirawat dengan baik, menggunakan benih unggul Biosoy. Lahan perlu diberi pupuk cair yang banyak mengandung bakteri penambat Nitrogen. Gulma rutin dibersihkan supaya tidak mengganggu pertumbuhan tanaman kedelai. Petani Desa Wonoharjo mendapat pengetahuan dari lahan percontohan yang ditanami kedelai.

Kegiatan pengabdian masyarakat dapat diperluas dan menambah aktivitas di desa. Bantuan edukasi kepada petani agar mau mencoba bertanam kedelai masih diperlukan. Petani didorong untuk menanam kedelai dengan pemberian benih unggul Biosoy, pupuk dan alat pengering hasil panen.

\section{UCAPAN TERIMA KASIH}

Benih kedelai varietas unggul baru kami terima dari Balai Penelitian Bioteknologi dan Pengembangan Sumberdaya Genetik, Departemem Pertanian (BB Biogen) di Bogor. Terima kasih kepada Ir. Mastur, M.Si. Ph.D. dan Dr. Edy Listanto, MP yang telah memberikan dan mengirimkan benih tersebut untuk penelitian mahasiswa maupun kegiatan pengabdian masyarakat.

\section{DAFTAR PUSTAKA}

Aldillah, R. (2015). Proyeksi produksi dan konsumsi kedelai Indonesia. Jurnal Ekonomi Kuantitatif Terapan, 8(1), 9-23. https://doi.org/10.24843/JEKT.2015.v08.i01.p02

Ardyawan, I., Raka, I., \& Artha, I. (2018). Pengaruh jenis rhizobakteria terhadap pertumbuhan dan hasil tanaman kedelai (Glycine max (L). Merril). Jurnal Agroekoteknologi Tropika (Journal of Tropical Agroecotechnology), 7(1), 93-102.

Astuti, D. T., Hawayanti, E., Afrizal, H. A., \& Sebayang, N. S. (2021). Respon pemupukan dan jarak tanam yang berbeda terhadap hasil tanaman kedelai. Jurnal Agrium, 18(2). 154-160. https:// doi.org/10.29103/agrium.v18i2.5334 
ABDIMAS: Jurnal Pengabdian Masyarakat Universitas Merdeka Malang

Volume 7, No 1, February 2022: 139-148

Badan Pusat Statistik. (2017). Produksi dan produktivitas tanaman kedelai Indonesia. Badan Pusat Statistik.

Dewi, N., Nugroho, K., Terryana, R. T., \& Lestari, P. (2020). Evaluation of SSR and important agronomical characters of promising mutant lines of soybean. Biodiversitas Journal of Biological Diversity, 21(1), 299-310. https://doi.org/10.13057/biodiv/d210137

Haryadi, N., Purnomo, H., \& Agusina, T. (2021). Empowerment of watermelon farmer at Mojosari Village Puger District Jember in producing watermelon low pesticide residue. Jurnal Pengabdian kepada Masyarakat (Indonesian Journal of Community Engagement), 7(3), 164-169. https://doi.org/10.22146/jpkm.38432

Mayarni, M., \& Habibie, D. K. (2019). Ekonomi politik dalam pengelolaan hutan Desa Kenegerian Gunung Sahilan. Jurnal Kebijakan Publik, 10(2), 67-74. http://dx.doi.org/10.33578/jkp.10.2.p.67-74

Mursalin, M., Achmad, E., \& Novra, A. (2020). Pengembangan tanaman sereh wangi untuk bioreklamasi lahan dan pemberdayaan ekonomi masyarakat di Muaro Jambi. Agrokreatif: Jurnal Ilmiah Pengabdian kepada Masyarakat, 6(3), 206-212. https://doi.org/10.29244/agrokreatif.6.3.206212

Pitasari, Y., Hudoyo, A., \& Soelaiman, A. (2019). Proyeksi stokastik produksi kedelai di Indonesia. Jurnal Ilmu Agribisnis: Journal of Agribusiness Science, 6(3), 229-235. http://dx.doi.org/10.23960/jiia.v6i3.3018

Puspitasari, A., \& Elfarisna, E. (2018). Respon pertumbuhan dan produksi kedelai varietas grobogan dengan penambahan pupuk organik cair dan pengurangan dosis pupuk anorganik. Prosiding Semnastan, 204-212.

Sari, V. K., Damanhuri, D., Erdiansyah, I., Eliyatiningsih, E., \& Pratama, A. W. (2020). Pelatihan enkapsulasi pupuk Rhizobium spp pada media cair dan granular untuk tanaman kedelai di Desa Sukorejo Kecamatan Bangsalsari Kabupaten Jember. Journal of Innovation and Applied Technology, 6(2), 1025-1030.

Septifani, R. (2018). Pemanfaatan ampas kedelai sebagai produk pangan dengan nilai tambah ekonomis di UKM Susu Kedelai Kota Batu. Journal of Innovation and Applied Technology, 4(2), 784-788. http://dx.doi.org/10.21776/ub.jiat.2018.004.02.10

Sumarmi, S., \& Triyono, K. (2018). Pertumbuhan dan hasil penananam kedelai (Glycine max L. Merrill) varietas Grobogan dan Anjasmoro akibat kekeringan di Sidoharjo, Kabupaten Wonogiri. Jurnal Innofarm, 20(2), 1-11.

Wahyudin, A., Wicaksono, F. Y., Irwan, A. W., Ruminta, R., \& Fitriani, R. (2017). Respons tanaman kedelai (Glycine max) varietas Wilis akibat pemberian berbagai dosis pupuk N, $\mathrm{P}, \mathrm{K}$, dan pupuk guano pada tanah Inceptisol Jatinangor. Jurnal Kultivasi, 16(2), 333-339. https://doi.org/10.24198/kultivasi.v16i2.13223 